\title{
STUDI KATALITIK EKSTRAK DAUN KAPUK RANDU (CEIBA PENTANDRA) UNTUK MENGOBATI PANAS DALAM
}

\author{
Putty Zinda Febrila \\ Jurusan Kimia, FMIPA, Universitas Negeri Padang, Indonesia \\ Email : puttyzinda21@gmail.com
}

\begin{abstract}
Abstrak. Studi ini bertujuan untuk membuat ekstrak daun kapuk randu (Ceiba Pentandra) untuk mengobati panas dalam. Metode yang dilakukan adalah eksperimen dan uji aktivitas katalitik secara langsung. Tahapan pertama yang dilakukan yaitu dengan mencuci daun kapuk randu, dilanjutkan meremas dengan air yang telah matang, lalu disaring, sehingga terbentuk ekstrak dari daun kapuk randu. Uji efektivitas langsung dilakukan dengan variasi jumlah ekstrak yang diminum selama 5 hari . Hasil eksperimen membuktikan bahwa ekstrak daun kapuk randu dapat mengobati panas dalam. Kondisi optimum ekstrak tercapai pada hari ke lima, dengan jumlah ekstrak yang diminum sebanyak $400 \mathrm{ml}$. Penyembuhan ini diduga karena aktivitas katalitik ekstrak daun kapuk randu terhadap tenggorokan dimana ekstrak daun kapuk randu mengandung polifenol, saponin, hidrat arang, dan flavonoid yang berfungsi sebagai antioksidan yang dapat menyembuhkan panas dalam.
\end{abstract}

Keywords : Katalitik, ekstrak, daun kapuk randu, panas dalam, polifenol, saponin, hidrat arang, flavonoid, antioksidan.

\section{PENDAHULUAN}

Reaksi-reaksi kimia [1] merupakan salah satu proses yang penting bagi kehidupan. Reaksi kimia terjadi pada semua makhluk hidup. Reaksi kimia merupakan suatu perubahan yang mengahasilkan zat baru. Terjadinya zat baru ini tidak dapat kembali ke bentuk asalnya, misalnya yaitu pembakaran, pembusukan dan perkaratan. Tanpa adanya reaksi kimia maka kehidupan tidak akan mungkin bisa berlangsung. Reaksi kimia menimbulkan manfaat bagi manusia di berbagai bidang. Tetapi selain bermanfaat, terjadinya reaksi kimia yang berlebihan juga akan merugikan manusia atau makhluk hidup itu sendiri.

Dalam ilmu kimia, terjadinya suatu reaksi dipengaruhi oleh suatu katalis. Katalis [2] merupakan zat yang dapat mempercepat terjadinya reaksi tanpa ikut bereaksi. Katalis terbagi menjadi dua yaitu katalis alami dan katalis buatan (sintetis). Katalis alami merupakan katalis yang bersifat herbal, biasanya berasal dari tumbuh-tumbuhan yang tersedia di alam. Sedangkan katalis sintetis [3] 
merupakan katalis yang sengaja dibuat oleh manusia untuk kepentingan tertentu. Katalis alami [4] dan katalis buatan memiliki kelebihan masing-masingnya. Tanpa adanya katalis maka reaksi akan berlangsung lambat. Cepat atau lambatnya reaksi ditentukan oleh katalis yang cocok digunakan pada suatu reaksi.

Kapuk randu (Ceiba Pentandra) [5] termasuk dalam kingdom Plantae [6] dengan genus Ceiba. Tanaman [7] ini memiliki batang berkayu yang besar dan tinggi yang berwarna hijau tua. Karena batangnya berkayu, biasanya dijadikan oleh manusia bahan pembuatan mebel atau furnitur [8] seperti meja, kursi, rak, dan lemari. Akar [9] tumbuhan ini adalah akar tunggang. Tumbuhan ini memiliki jenis daun tunggal dengan tulang daun [10] menjari. Salah satu spesifik dari tumbuhan [11] ini adalah memiliki buah yang lonjong berwarna hijau yang di dalamnya terdapat serat halus atau yang dikenal sebagai kapuk. Apabila buahnya sudah tua maka warnanya akan berubah menjadi coklat dan kapuk yang ada di dalamnya akan keluar dengan sendirinya. Kapuk inilah yang dimanfaatkan oleh manusia sebagai bahan pengisi bantal atau boneka. Kapuk tersebut berwarna putih, halus dan sangat ringan.

Selain manfaat diatas, kapuk randu juga bermanfaat di bidang kesehatan. Daun kapuk randu banyak digunakan sebagai obat dari berbagai penyakit. Penyakit-penyakit tersebut antara lain panas dalam, penghilang bekas luka, diare, dan masih banyak lagi. Pengobatan dengan daun kapuk randu ini termasuk pengobatan herbal atau tradisional [12], karena berasal dari tumbuh-tumbuhan secara alami. Sekarang ini banyak orang yang lebih memilih pengobatan herbal disamping pengobatan medis. Karena obat herbal biayanya lebih murah dan khasiatnya juga menjanjikan. Disamping itu obat herbal juga tidak mempunyai efek samping.

Panas dalam merupakan suatu gangguan yang biasanya terjadi di dalam mulut. Biasanya diikuti dengan tenggorokan kering dan bibir pecah-pecah. Panas dalam merupakan salah satu gelaja demam atau diare. Panas dalam disebabkan karena kekurangan vitamin $\mathrm{C}$ dan air putih. Panas dalam bisa ditanggulangi dengan banyak minum air serta memakan makanan yang mengandung banyak serat seperti buah [13] dan sayur. Untuk meredakan panas dalam dengan cepat, dapat dipakai suatu katalis [14] seperti dengan ekstrak daun kapuk randu. Ekstrak [15] tersebut dibuat dengan meremas daun kapuk randu dengan air, lalu disaring. Ekstrak atau hasil sintesis [16] tersebut kemudian diminum secara teratur sampai panas dalam tersebut sembuh.

Berdasarkan informasi turun temurun, daun kapuk randu bisa digunakan untuk mengobati panas dalam. Tujuan dari paper ini adalah untuk mengetahui, apakah ekstrak daun kapuk randu mampu mengobati panas dalam ? 


\section{METODE}

A. Alat dan bahan

Peralatan yang digunakan untuk membuat ekstrak daun kapuk randu yaitu mangkok (Aeco), saringan (613 PUP 3), gelas (Royalex $200 \mathrm{ml}$ ), sendok (Stainless Steel No.888), periuk (sakito), kompor gas (Rinnai), dan kamera (Oppo A37). Bahan yang digunakan adalah daun kapuk randu yang diambil dari Payobadar, Payakumbuh Timur, Kota Payakumbuh dan air (Asri).

B. Prosedur Kerja

1. Penyiapan sampel

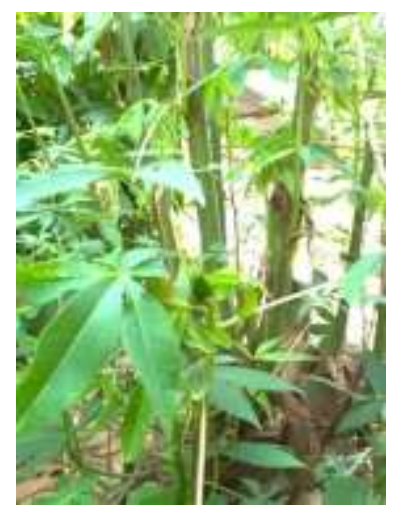

Gambar 1. Pohon Kapuk Randu Randu

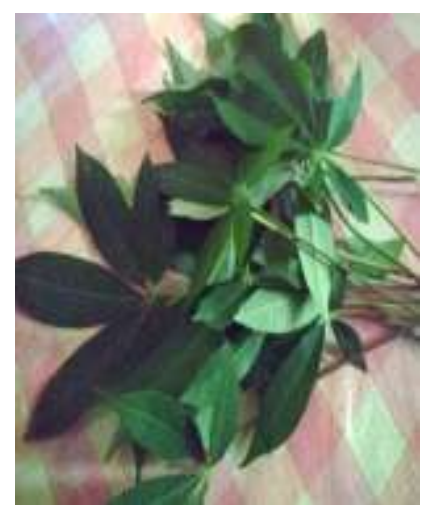

Gambar 3. Daun Kapuk Randu

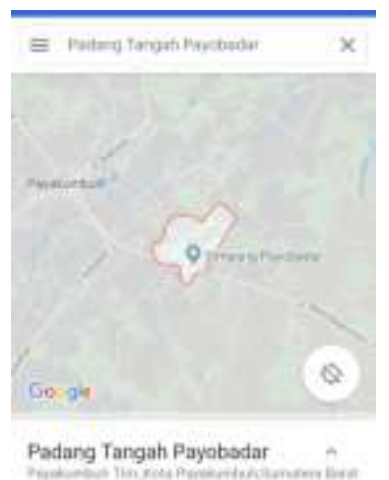

Gambar 2. Lokasi Kapuk

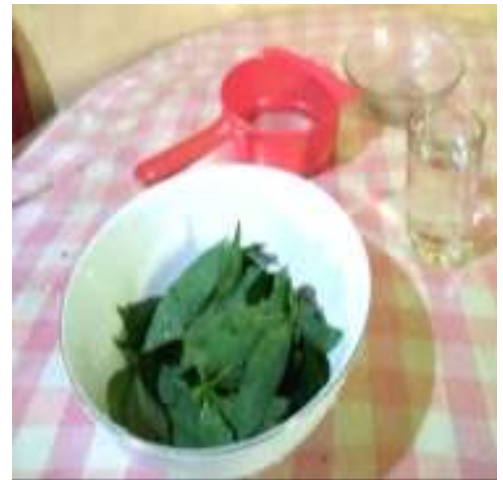

Gambar 4. Alat dan Bahan

2. Pembuatan ekstrak

Ekstrak dibuat dengan cara mengambil 10 helai (50 gram) daun kapuk randu. Kemudian daun tersebut dicuci dengan air mengalir sampai kotorannya benar-benar hilang ( \pm 3 menit). Kemudian daun kapuk randu tersebut diremas dengan $200 \mathrm{ml}$ air yang telah matang. Selanjutnya hasil remasan disaring menggunakan penyaring. Setelah disaring maka didapatlah ekstrak daun kapuk randu yang kental dan berwarna hijau sebanyak $175 \mathrm{ml}$. 


\section{Pengujian Ekstrak}

Ekstrak yang sudah jadi dicobakan dengan variasi jumlah ekstrak selama 5 hari, yaitu hari pertama $200 \mathrm{ml}$, hari kedua $250 \mathrm{ml}$, hari ketiga $300 \mathrm{ml}$, hari keempat $350 \mathrm{ml}$, dan hari kelima $400 \mathrm{ml}$. Hasil yang sudah jadi ditanyakan kepada yang bersangkutan. Ternyata pada hari kelima panas dalam yang diderita hilang.

Metode ini dapat dibuat secara diagram sebagai berikut :

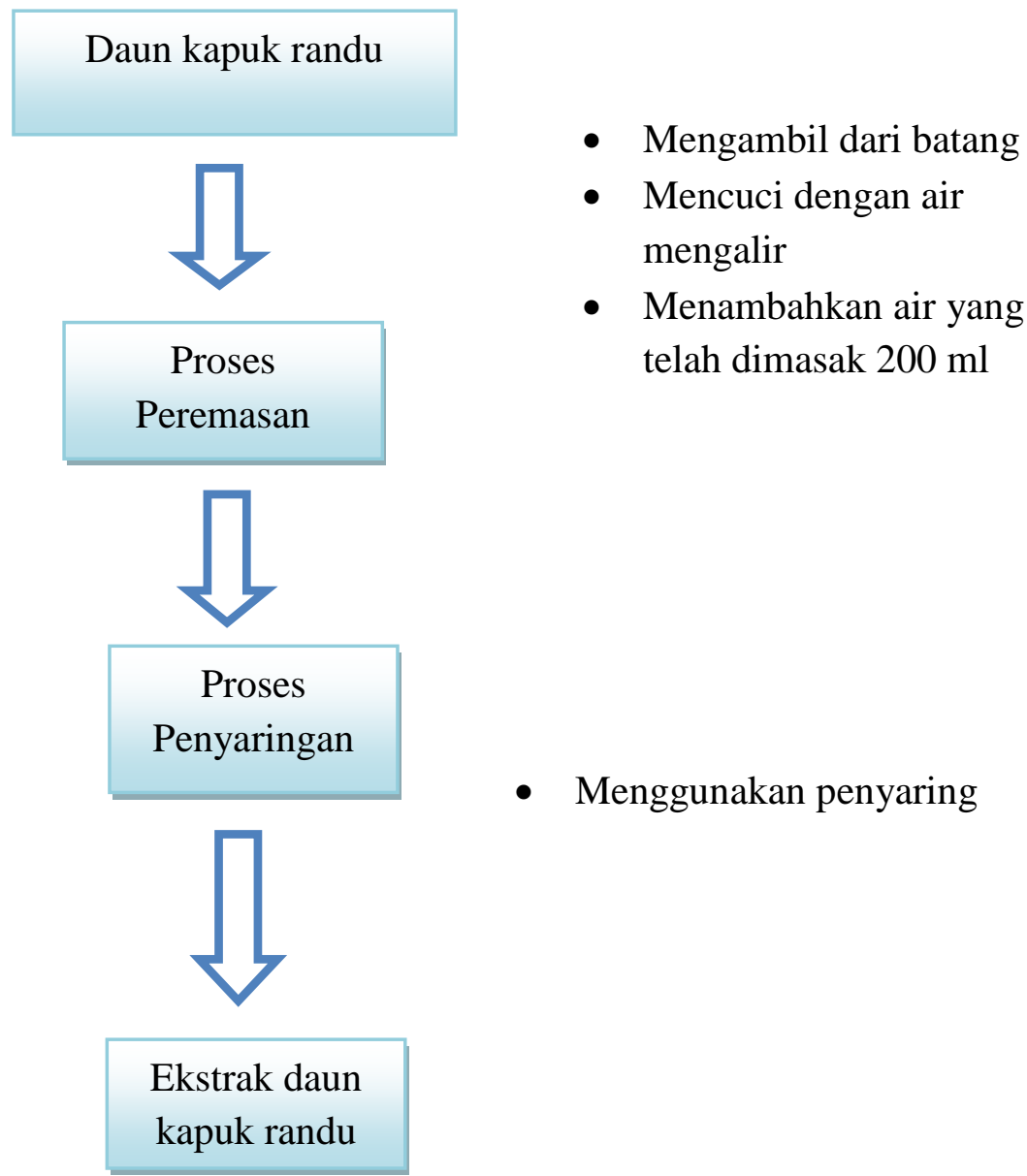

III. HASIL

1. Hasil Pembuatan

Pembuatan ekstrak dari 50 gram daun kapuk randu dalam 200 ml air diperoleh ekstrak sebanyak $175 \mathrm{ml}$. 
Hal ini dapat dilihat dari gambar berikut :

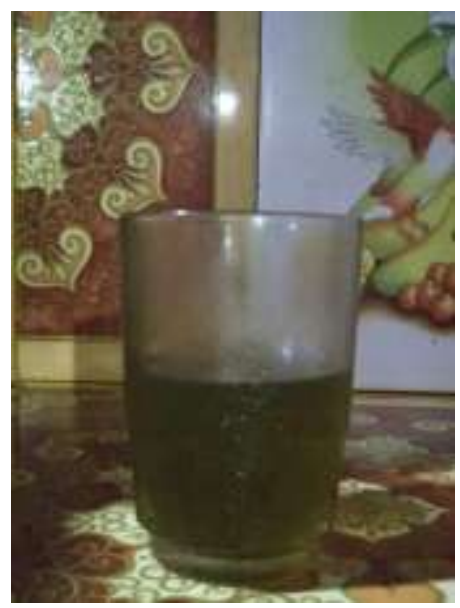

\section{Gambar 5. Ekstrak Daun Kapuk Randu}

2. Hasil uji coba

Pengujian dilakukan terhadap orang ternyata berhasil mengobati panas dalam setelah beberapa hari. Penjelasan pada tabel :

\begin{tabular}{|l|l|l|}
\hline Hari ke & $\begin{array}{l}\text { Jumlah ekstrak yang } \\
\text { diminum }\end{array}$ & Kadar panas dalam \\
\hline 1 & $200 \mathrm{ml}$ & $100 \%$ \\
\hline 2 & $250 \mathrm{ml}$ & $80 \%$ \\
\hline 3 & $300 \mathrm{ml}$ & $50 \%$ \\
\hline 4 & $350 \mathrm{ml}$ & $20 \%$ \\
\hline 5 & $400 \mathrm{ml}$ & $0 \%$ \\
\hline
\end{tabular}

\section{PEMBAHASAN}

\section{Pembuatan}

Langkah awal yaitu pencucian daun kapuk randu sebanyak 10 helai (50 gram). Pencucian dilakukan dengan air mengalir sampai bersih, lebih kurang selama 3 menit. Tujuan dari pencucian ini yaitu membersihkan kotorankotoran yang menempel pada daun [17]. Selanjutnya daun kapuk randu dimasukkan ke dalam mangkok dan ditambahkan $200 \mathrm{ml}$ air yang sudah dimasak. Kemudian daun tersebut diremas untuk diambil ekstraknya. Dalam proses peremasan, pastikan semua daun kapuk randu habis teremas sampai yang tersisa hanyalah ampasnya [18]. Kemudian saring hasil remasan tersebut dengan penyaring. Di bawah penyaring letakkan gelas sebagai wadah penampung ekstrak.. Setelah disaring ekstrak daun kapuk randu siap diminum. Dari 50 gram daun kapuk randu dan $200 \mathrm{ml}$ air dihasilkan $175 \mathrm{ml}$ ekstrak daun 
kapuk randu. Kendala yang dialami pada proses ini yaitu saat pengambilan daun kapuk randu. Pohon kapuk randu sangat tinggi dan besar serta letaknya pada semak-semak, sehingga untuk pengambilan daun agak kesulitan. Hambatan lain yaitu pada proses pencucuian yang agak lama, karena banyak semut hitam yang menempel pada daun. Kemudian proses penyaringan juga berlangsung lambat karena ekstraknya sangat kental.

2. Uji coba

Setelah selesai penyaringan, ekstrak daun kapuk randu siap diminum. Saat pengujian, ekstrak diminum dengan variasi yang berbeda.

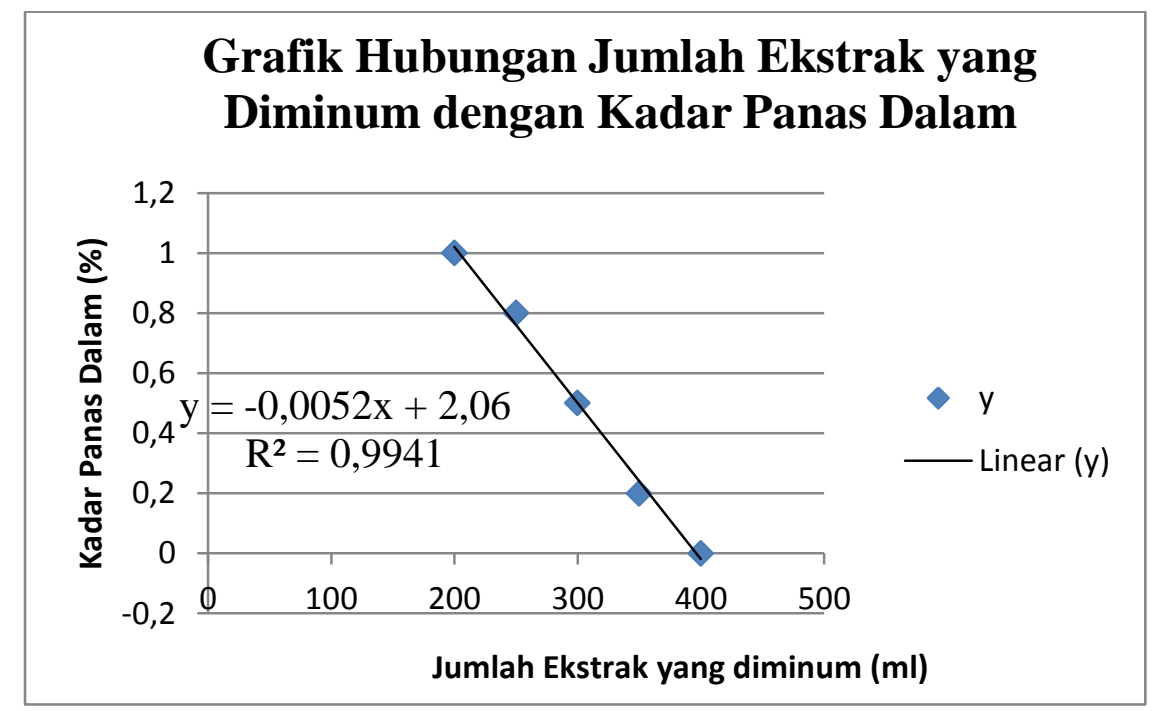

Dari grafik diatas menjelaskan hubungan antara jumlah ekstrak yang diminum (ml) dengan kadar [19] panas dalam. Dapat dilihat pada grafik, grafik cenderung menurun.

Grafik dapat dijelaskan sebagai berikut :

- Pada hari pertama jumlah ekstrak yang dikonsumsi $200 \mathrm{ml}$, dengan persentase panas dalam $100 \%$.

- Pada hari kedua jumlah ekstrak yang dikonsumsi $250 \mathrm{ml}$, dengan persentase panas dalam $80 \%$.

- Pada hari ketiga jumlah ekstrak yang dikonsumsi $300 \mathrm{ml}$, dengan persentase panas dalam $50 \%$.

- Pada hari keempat jumlah ekstrak yang dikonsumsi $350 \mathrm{ml}$, dengan persentase panas dalam $20 \%$.

- Pada hari kelima jumlah ekstrak yang dikonsumsi $400 \mathrm{ml}$, dengan persentase panas dalam $0 \%$. 
Maka dari grafik dapat disimpulkan semakin banyak jumlah ekstrak kapuk randu yang dikonsumsi maka maka panas dalam semakin cepat hilang. Hal ini terjadi pada hari kelima, dimana ekstrak daun kapuk randu yang dikonsumsi $400 \mathrm{ml}$ dan kadar panas dalam sebanyak $0 \%$ (panas dalam hilang). Jadi kondisi optimum terjadi pada hari kelima.

Di dalam ekstrak daun kapuk randu terkandung polifenol, saponin, hidrat arang, dan flavonoid yang bisa dijadikan sebagai indikator penurunan panas pada tubuh, sehingga bisa digunakan untuk mengobati panas dalam. Polifenol, saponin, hidrat arang dan flavonoid [20] ini berfungsi sebagai antioksidan [21] yang memperlambat proses oksidasi molekul lain. Oksidasi dapat menghasilkan radikal bebas [22] yang memicu reaksi [23] berantai yang merusak sel.

Diketahui juga bahwa ekstrak daun kapuk randu yang mengandung polifenol, saponin, hidrat arang dan flavonoid merupakan cairan yang memiliki suhu [24] yang dingin sehingga mampu meredakan panas dalam. Pengobatan melalui ekstrak daun randu ini merupakan cara herbal, berasal dari tumbuh-tumbuhan yang ada di alam [25]. Ekstrak tersebut yang berupa gel [26] berwarna hijau bisa dijadikan alternatif pengobatan, disamping pengobatan medis. Ekstrak ini akan mengobati mulai dari sel (cell) [27] hingga jaringan tubuh yang rusak akibat panas dalam. Selain mudah didapat, harganya murah, obat [28] herbal ekstrak daun kapuk randu tidak memiliki efek samping dan tidak menimbulkan dampak negatif bagi lingkungan. Jika setiap proses pembuatan ekstrak mulai dari pencucian, peremasan hingga penyaringan dilakukan dengan baik, maka akan menghasilkan ekstrak yang berkualitas tinggi [29]. Pencampuran antara daun kapuk randu dan air merupakan metode blending yaitu salah satu metode atau proses material [30] dengan cara kerjanya menggabungkan bahan material dalam jumlah yang ditentukan . Air [31] yang ditambahkan di adsorbsi oleh daun kapuk randu membentuk gel. Metode katalitik ini merupakan salah satu penerapan dari ilmu kimia [32] yang bisa diterapkan dalam kehidupan sehari-hari oleh manusia [33]. Disamping bisa mengobati panas dalam, ekstrak daun kapuk randu kaya akan vitamin C [34] dan bersifat pendingin [35] sehingga sangat bermanfaat bagi tubuh. Itulah beberapa kandungan ekstrak daun kapuk randu yang bisa digunakan untuk mengobati panas dalam, selain dengan pengobatan medis. 
Berikut akan diuraikan beberapa kandungan [36] ekstrak daun [37] kapuk randu (Ceiba Pentandra) yang sangat bermanfaat bagi manusia [38] diantaranya yaitu polifenol, saponin, hidrat arang dan flavonoid [39]. Polifenol merupakan suatu senyawa [40] kimia yang [41] baik untuk [42] kesehatan [43]. Dilihat dari namanya polifenol, poli yang berarti banyak [44] dan [45] fenol artinya alkohol. Jadi polifenol banyak mengandung gugus alkohol. Selain bermanfaat untuk meredakan panas dalam, ternyata polifenol digunakan untuk menyembuhkan berbagai penyakit [46]. Diantaranya bersifat [47] sebagai [48] antioksidan yang [49] mampu menangkal radikal bebas untuk [50] mencegah kanker. Selain itu dapat mencegah diabetes [51] dan [52] bisa juga menyembuhkan penyakit jantung. Polifenol banyak terdapat pada tumbuhan (plant) [53] seperti kacang-kacangan, teh [54] hijau, anggur dan masih banyak lagi. Polifenol umumnya banyak tedapat pada buah-buahan dan sayur-sayuran. Mengingat begitu banyaknya manfaat yang terkandung dalam polifenol, maka manusia dianjurkan untuk banyak mengonsumsi buah-buahan serta sayur-sayuran. Polifenol juga memberikan warna [55] pada buah-buahan misalnya pada anggur.

Kandungan pada tumbuhan (plant) [56] kapuk randu selanjutnya yaitu saponin. Saponin umumnya terdapat pada tumbuh-tumbuhan di berbagai lingkungan yang beragam (various enviromental) [57] baik tumbuhan yang hidup di darat (land plant) [58] maupun di air (aquatic plant, dimana lingkungan (environment) [59] sangat mempengaruhi pertumbuhan tumbuhan tersebut bila dilihat dari kualitas lingkungannya (enviromental quality) [60]. Terkadang, beberapa kondisi (some conditions) [61] menyebabkan tumbuhan tidak tumbuh dengan baik, jadi lokasi (location) [62] tumbuh juga berpengaruh terhadap tumbuhan (plant) [63] dan secara tidak langsung juga akan berpengaruh pada kehidupan manusia (human life) [64] mengenai berbagai masalah kesehatan (various health problem) [65]. Populasi (population) [66] tumbuhan yang mengandung saponin sangat banyak, karena begitu besar manfaatnya bagi kesehatan (health) [67]. Umumnya saat ini banyak masyarakat yang memilih obat herbal untuk menjaga kesehatan (health care) [68]. Hasil (the result) [69] dari pengobatan secara herbal bersifat ramah lingkungan dan tidak menyebabkan efek samping bila dibandingkan dengan obat hasil industri (industries) [70] farmasi menurut observasi (observe) [71]. Pengobatan herbal ini banyak dipilih oleh masyrakat dari berbagai kalangan usia, baik anak-anak (children) [72] maupun orang dewasa bahkan lansia. Artinya metode (method) [73] pengobatan herbal bisa dipilih sebgai alternatif pengobatan di samping pengobatan medis. Saat ini banyak masyarakat Indonesia yang berusaha meningkatkan (increase) [74] 
kondisi kesehatan dengan berbagai jenis tumbuhan herbal. Hal ini juga didukung oleh berbagai penelitian mengenai manfaat bahan-bahan (material) [75] alami. Bahan-bahan alami (natural) [76] juga mudah di dapat dan harganya juga terjangkau oleh masyarakat. Saponin terdapat pada semua organ tumbuhan baik itu akar, batang dan daun. Saponin juga merupakan [77] senyawa [78] kimia (chemistry) [79] yang mengandung banyak manfaat. Salah satu ciri khas yang menonjol dari saponin yaitu bila dikocok dengan air dengan temperature [80] kamar akan mengeluarkan busa yang [81] banyak [82]. Saponin memiliki rasa yang pahit, membentuk busa stabil dalam air [83], serta berbahaya bagi ikan dan amfibi. Saponin pada tumbuhan terbagi dua yaitu saponin steroid dan saponin triterpenoid. Saponin merupakan senyawa kimia yang bisa dimanfaatkan sebagai [84] obat herbal.

Hidrat arang adalah [85] senyawa kimia yang juga terdapat pada ekstak daun kapuk randu. Hidrat arang merupakan senyawa yang juga dimanfaatkan sebagai obat herbal, sehingga menjadi topik yang menarik (interesting) [86] untuk melakukan penelitian. Hidrat arang disebut juga dengan sakarida terdiri dari unsur karbon, hidrogen dan oksigen yang terkandung dalam ekstrak daun kapuk randu sebgai katalis [87] dalam penyembuhan panas dalam. Hidrat arang atau dikenal dengan karbohidrat merupakan [88] sumber energi bagi manusia. Molekul [89] Karbohidrat dijadikan sebagai [90] makanan pokok bagi manusia, biasanya terdapat pada padi, jagung, gandum dan sagu. Di Indonesia [91] karbohidrat merupakan senyawa [92] yang umumnya dijadikan makanan pokok adalah [93] padi. Tetapi di daerah Indonesia Timur ditemukan [94] makanan pokok masyarakatnya adalah sagu. Karbohidrat merupakan senyawa [95] yang apabila jumlahnya berlebih di dalam tubuh manusia [96] akan disimpan sebagai cadangan makanan yang menyebabkan pertumbuhan sekunder pada manusia. Senyawa [97] karbohidrat terdiri dari senyawa [98] karbohidrat sederhana dan senyawa [99] karbohidrat kompleks.

Senyawa [100] selanjutnya yang terkandung dalam ekstrak daun kapuk randu adalah flavonoid. Flavonoid dalam ekstrak tersebut langsung berinteraksi (interact) [101] dengan bagian tubuh yang mengalami panas dalam. Flavonoid merupakan senyawa [102] fitokimia yang umumnya terdapat pada semua organ tumbuhan, baik itu akar, batang dan daun. Flavonoid mempunyai manfaat yang sangat besar bagi manusia (human) [103] yaitu diperlukan [104] dalam mencegah dari banyak [105] penyakit. Flavonoid juga bersifat ramah lingkungan (environment) [106] karena bersifat herbal dan juga hemat secara ekonomi (economically) [107]. Perkembangan teknologi [108] membuat manuasia banyak melakukan 
penelitian terhadap senyawa herbal. Flavonoid adalah salah satu senyawa yang sangat popular [109] sebgagai objek penelitian. Salah satunya [110] pembuatan ekstrak daun kapuk randu ini yang bahannya mudah di dapat di lingkungan [111] baik di lingkungan darat maupun air [112]. Apabila suatu tumbuhan mengandung senyawa [113] flavonoid, maka dapat dikatakan tumbuhan tersebut mengalami metabolit sekunder. Flavonoid juga mengandung banyak manfaat bagi manusia yaitu berfungsi sebagai antioksidan yang dapat menangkal radikal bebas yang sangat berbahaya bagi manusia. Sama halnya dengan polifenol, flavonoid juga dapat mencegah kanker, diabetes mellitus [114] darah tinggi (hipertensi) dan serangan jantung. Karena memiliki manfaat yang begitu besar, maka tumbuhan yang mengandung flavonoid banyak dijadikan untuk [115] mengobati berbagai penyakit.

Dari uraian diatas, terlihat jelas bahwa tumbuhan [116] banyak mengandung senyawa-senyawa fitokimia yang bermanfaat bagi manusia. Senyawa fitokimia dapat digunakan sebagai obat [117] bagi manusia. Dengan memanfaat tumbuhan sebagai objek pengobatan herbal, maka secara tidak langsung kearifan lokal [118] sudah dilestarikan. Karena pada dasarnya tumbuhan herbal sudah dimanfaatkan sejak ribuan tahun lalu [119] oleh nenek moyang terdahulu sebagai media pengobatan. Sumber daya alam merupakan kekayaan bumi yang dimanfaatkan untuk kesejahteraan manusia [120]. Polifenol [121], saponin [122], hidrat arang, dan flavonoid [123] merupakan beberapa senyawa yang termasuk senyawa metabolit sekunder [124] yang ada pada tanaman [125]. Senyawa-senyawa [126] tersebut umumnya terdapat di semua organ [127] tumbuhan, baik itu akar [128], batang [129] dan daun [130], sehingga tumbuhan [131] tersebut bisa dikatakan metabolit sekunder [132].

Ekstrak [133] daun [134] kapuk randu ini dapat mengobati penyakit [135] panas dalam. Penyakit panas dalam terjadi pada rongga mulut [136]. Apabila diminum, kandungan [137] fitokimia langsung berinteraksi dengan bagian mulut yang mengalami panas dalam. Maka disinilah kandungan-kandungan senyawa [138] fitokimia tersebut bereaksi, yaitu mulai dari polifenol, saponin, hidrat arang, dan flavonoid. Masing-masing senyawa tersebut memiliki [139] struktur dan rumus kimia [140] yang berbeda, tetapi sama-sama memiliki manfaat [141] yang besar untuk kesehatan [142] manusia [143], baik untuk mencegah [144] penyakit maupun mengobati penyakit [145]. Kapuk randu merupakan [146] tanaman [147] yang bermanfaat bagi manusia. Selain daun, bagian tubuh tumbuhan kapuk randu yang lain juga bermanfaat bagi makhluk hidup [148] terutama manusia. Misalnya masyarakat [149] Indonesia [150] 
banyak memanfaatkan sebagai pengisi bantal. Kayu dari batangnya banyak dijadikan furniture, dan berbagai manfaat lainnya.

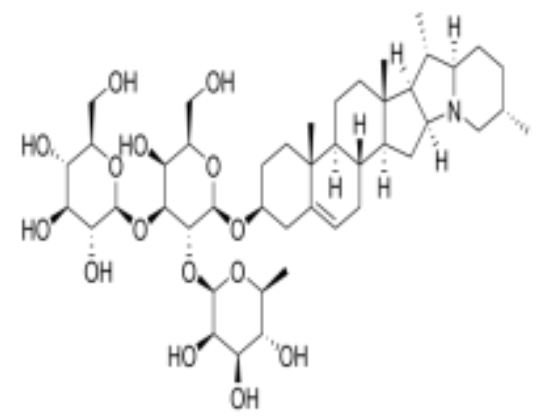

Gambar 6. Saponin

(https://www.google.com/search?q=saponin\&safe=strict\&source=lnms\&tbm=isch

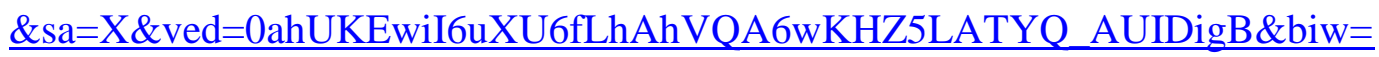
1366\&bih=657\#imgrc=zkZO8vWlyNS8xM: )

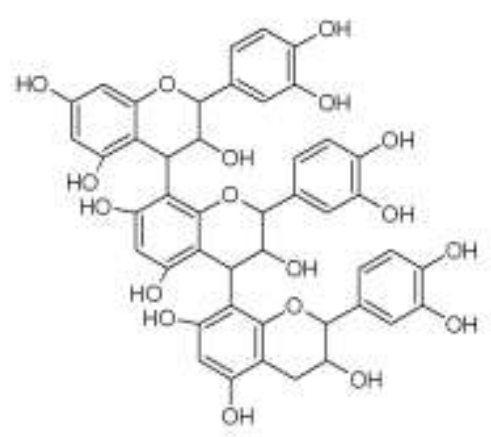

Gambar 7. Polifenol

(https://www.google.com/search?q=polifenol\&safe=strict\&source=lnms\&tbm=isc h\&sa=X\&ved=0ahUKEwiDkuHW6fLhAhUESK0KHaELCv8Q_AUIDigB\&biw $=1366 \&$ bih=657\#imgrc=1hC1MRzKQBI--M: )<smiles>O=c1cc(-c2ccccc2)oc2ccccc12</smiles>

Gambar 8. Flavonoid

(https://www.google.com/search?q=flavonoid\&safe=strict\&source=lnms\&tbm=is ch\&sa=X\&ved=0ahUKEwj3mJLZ6fLhAhVCJKwKHQ4YCNAQ_AUIDigB\&bi $\underline{\mathrm{w}=1366 \& \text { bih=657\#imgrc }=\text { QhTR84qh2e7BqM: ) }}$ 


\section{KESIMPULAN}

1. Ekstrak bisa dibuat dengan 50 gram daun kapuk randu dan $200 \mathrm{ml}$ air menghasilakan ekstrak sebanyak $175 \mathrm{ml}$.

2. Ekstrak dapat menyembuhkan panas dalam

3. Ekstrak dapat meredakan panas dalam karena karena mengandung polifenol, saponin, hidrat arang dan flavonoid.

\section{REFERENSI}

[1] Erawati Dewi, Luh Joni.2009. PENGEMBANGAN MEDIA PEMBELAJARAN REAKSI KESETIMBANGAN KIMIA. JPTK. Vol. 6. No.2.

[2] Mukaromah, Ana Hidayati, Irawan, Bagus. 2008. Pemanfaatan Reaktor Membran Fotokatalitik dalam Mendegradasi Fenol dengan Katalisis TiO2 dengan Adanya Ion Logam $\mathrm{Fe}($ III) dan $\mathrm{Cu}(\mathrm{II})$. PROSIDING SEMINAR NASIONAL. Vol. 1. No.1.

[3] Yusnitati, Yusnitati. 2006. EFEKTIVITAS PENAMBAHAN NIKEL PADA PENCAIRAN BATUBARA PERINGKAT RENDAH MENGGUNAKAN KATALIS ALAMI LIMONIT. Jurnal Energi dan Lingkungan (Enerlink). Vol. 2. No.1.

[4] Al Hakimi, Nurush Shofi, Hanapi, Ahmand, Fasya, Ahmad Ghanaim. 2017. Green Synthesis Senyawa Imina dari Vanillin and Anilina dengan Katalis Alami Air Jeruk Nipis (Citrus aurantifolia). ALCHEMY Journal of Chemistry. Vol. 5.No.4.

[5] Ningrum, Naliawati Prastiya Indra Kusuma, Muhamad Alfin Rokhati, Nur. 2013. PEMANFAATAN MINYAK GORENG BEKAS DAN ABU KULIT BUAH KAPUK RANDU (SODA QIE) SEBAGAI BAHAN PEMBUATAN SABUN MANDI ORGANIK BERBASIS TEKNOLOGI RAMAH LINGKUNGAN. JURNAL TEKNOLOGI KIMIA DAN INDUSTRI. Volume 2. Nomor 2.

[6] Kondo, Sarah. 2016. IMPLEMENTASI MEDIA PEMBELAJARAN GAMBAR BERBASIS INTERNET DALAM BELAJAR PLANTAE PADA SISWA SMA YPPKK MORIA KOTA SORONG. Jurnal Biolearning. Vol. 7.No. 1.

[7] Winardiantika, Dody Kastono, Sri Trisnowati, Venti. 2012. Pengaruh Waktu Pangkas Pucuk dan Frekuensi Pemberian Paklobutrazol terhadap Pertumbuhan dan Pembungaan Tanaman Kembang Kertas (Zinnia elegans Jacq.). Jurnal Budidaya Pertanian. Vol.1. No 2.

[8] Wardani, Laksmi Kusuma. 2010.PERANCANGAN FURNITUR PERKANTORAN (Proses Desain, Manufaktur, Distribusi, dan Konsumsi). Jurnal Dimensi Interior. Vol. 8.No 1. 
[9] Nur Shinta Febriani, Didik Indradewa, dan Sriyanto Waluyo, Dwi. 2012. Pengaruh Pemotongan Akar dan Lama Aerasi Media Terhadap Pertumbuhan Selada (Lactuca sativa L.) Nutrient Film Technique. Jurnal Budidaya Pertanian. Vol. 1. No 1.

[10] Rustiani, Ummu Salamah Endah, Ariningsih Salji Nurjanah, Nurjanah Prasetiawan, AndiNurmaida, Nurmaida. 2015. Deteksi Bakteri Penyebab CVPD pada Jeruk Menggunakan DNA Asal Tulang Daun. Jurnal Fitopatologi Indonesia. Vol. 11. No 3.

[11] Sari, A. (2017) "POTENSI ANTIOKSIDAN ALAMI PADA EKSTRAK DAUN JAMBLANG (Syzigium cumini (L.) Skeels)”, EKSAKTA: Berkala Ilmiah Bidang MIPA, 18(02), pp. 107-112. doi: 10.24036/eksakta/vol18iss02/61.

[12] Huda, N. (2017) "PENGARUH EKSTRAK SAMBILOTO (Andrographis paniculata Nees.) TERHADAP SIKLUS ESTRUS MENCIT (Mus musculus L. Swiss Webster)", EKSAKTA: Berkala Ilmiah Bidang MIPA, 18(02), pp. 69-76. doi: 10.24036/eksakta/vol18-iss02/55.

[13] Mulia, M. (2017) "ISOLASI KUMARIN DARI KULIT BUAH LIMAU SUNDAI (Citrus nobilis Lour)", EKSAKTA: Berkala Ilmiah Bidang MIPA, 18(02), pp. 137-145. doi: 10.24036/eksakta/vol18-iss02/70.

[14] Sanjaya, H. (2018) "DEGRADASI METIL VIOLET MENGGUNAKAN KATALIS ZnO-TiO2 SECARA FOTOSONOLISIS”, EKSAKTA: Berkala Ilmiah Bidang MIPA, 19(1), pp. 91-99. doi: 10.24036/eksakta/vol19iss $1 / 131$.

[15] Rizki Saputra, M. and Sumarmin, R. (2018) “PENGARUH EKSTRAK DAUN SIRIH MERAH (Piper crocatum Ruiz \& Pav.) TERHADAP GLUKOSA DARAH MENCIT (Mus musculus L.) JANTAN YANG DIINDUKSI SUKROSA", EKSAKTA: Berkala Ilmiah Bidang MIPA, 19(1), pp. 43-55. doi: 10.24036/eksakta/vol19-iss1/124.

[16] Ningsih, S. K. (2017) "SINTESIS DAN KARAKTERISASI NANOPARTIKEL ZnO DOPED Cu2+ MELALUI METODA SOLGEL”, EKSAKTA: Berkala Ilmiah Bidang MIPA, 18(02), pp. 39-51. doi: 10.24036/eksakta/vol18-iss02/51.

[17] Chatri, M., Mansyurdin, M., Bakhtiar, A. and Adnadi, P. (2017) "PERBANDINGAN KOMPONEN MINYAK ATSIRI ANTARA DAUN MUDA DAN DAUN DEWASA PADA HYPTIS SUAVEOLENS (L.)POIT', EKSAKTA: Berkala Ilmiah Bidang MIPA, 18(02), pp. 1-12. doi: 10.24036/eksakta/vol18-iss02/41.

[18] Horiza, H. (2018) "The influence of the use of activated carbon Fibres of the cane Against the drop in Salinity In the well Dig In RT 003 RW 006 Village Cape Town Unggat Tanjungpinang Year 2017”, EKSAKTA: Berkala Ilmiah Bidang MIPA, 19(1), pp. 1-6. doi: 10.24036/eksakta/vol19-iss1/97. 
[19] Ruswandi, R. (2018) "Determination of Fructose Content resulted by Inulin Hydrolysis with DNS as Oxidizer”, EKSAKTA: Berkala Ilmiah Bidang MIPA, 19(1), pp. 14-23. doi: 10.24036/eksakta/vol19-iss1/102.

[20] Parbuntari, H., Prestica, Y., Gunawan, R., Nurman, M. and Adella, F. (2018) "Preliminary Phytochemical Screening (Qualitative Analysis) of Cacao Leaves (Theobroma cacao L.)”, EKSAKTA: Berkala Ilmiah Bidang MIPA, 19(2), pp. 40-45. doi: 10.24036/eksakta/vol19-iss2/142.

[21] Sari, A. (2017) "POTENSI ANTIOKSIDAN ALAMI PADA EKSTRAK DAUN JAMBLANG (Syzigium cumini (L.) Skeels)”, EKSAKTA: Berkala Ilmiah Bidang MIPA, 18(02), pp. 107-112. doi: 10.24036/eksakta/vol18iss02/61.

[22] Sumarmin, R. (2018) "Pengaruh Ekstrak Kulit Buah Manggis (Garcinia mangostana L.) terhadap Histologis Pankreas Mencit (Mus musculus L. Swiss Webster) yang Diinduksi Sukrosa”, EKSAKTA: Berkala Ilmiah Bidang MIPA, 19(1), pp. 100-112. doi: 10.24036/eksakta/vol19-iss1/123.

[23] Hidayani, T. (2018) "GRAFTING POLIPROPILENA DENGAN MALEAT ANHIDRIDA SEBAGAI PENGIKAT SILANG DENGAN INISIATOR BENZOIL PEROKSIDA", EKSAKTA: Berkala Ilmiah Bidang MIPA, 19(1), pp. 56-62. doi: 10.24036/eksakta/vol19-iss1/127.

[24] Syafei, N. (2018) "Riset Material ANALISA FENOMENA KOROSI PELAT PIPA BAJA KARBON API 5L-X65 DALAM LARUTAN $7900 \mathrm{ML}$ AIR LAUT DAN 100 ML AMONIAK PADA KONDISI GAS CO2 DAN H2S JENUH PADA SUHU RUANG.”, EKSAKTA: Berkala Ilmiah Bidang MIPA, 19(1), pp. 7-13. doi: 10.24036/eksakta/vol19-iss 1/83.

[25] Samah, S. (2017) “KARAKTERISASI PLASTIK BIODEGRADABEL DARI LDPE-g-MA DAN PATI TANDAN KOSONG SAWIT”, EKSAKTA: Berkala Ilmiah Bidang MIPA, 18(02), pp. 30-38. doi: 10.24036/eksakta/vol18-iss02/48.

[26] Liza, Y. M., Yasin, R. C., Maidani, S. S., \& Zainul, R. (2018, October 9). SOL GEL : PRINCIPLE AND TECHNIQUE (A REVIEW). https://doi.org/10.31227/osf.io/2cuh8

[27] Zainul, R. (2018, August 16). Design and Modification of Copper Oxide Electrodes for Improving Conversion Coefficient Indoors Lights (PV-Cell) Photocells. https://doi.org/10.31227/osf.io/pgn84

[28] Feronika, N. I., \& Zainul, R. (2018, November 19). Kalium Permanganat: Termodinamika Mengenai Transport Ionik dalam Air. https://doi.org/10.31227/osf.io/g6eyk

[29] Dinata, A. A., Rosyadi, A. M., Hamid, S., \& Zainul, R. (2018, October 15). A Review CHEMICAL VAPOR DEPOSITION : PROCESS AND APPLICATION. https://doi.org/10.31227/osf.io/yfeau 
[30] Putri, D. F., Ritonga, H. M., Murdiati, V., \& Zainul, R. (2018, October 15). A REVIEW WHAT IS HYDROTHERMAL ?. https://doi.org/10.31227/osf.io/dm56c

[31] Husna, H., \& Zainul, R. (2019, February 3). A Review : Aspek Termodinamika dalam LiNO3 Larutannya. https://doi.org/10.31227/osf.io/45mbd

[32] Guci, S. R. F., Zainul, R., \& Azhar, M. (2018, September 19). PENGEMBANGAN MEDIA PEMBELAJARAN BERBASIS TIGA LEVEL REPRESENTASI MENGGUNAKAN PREZI PADA MATERI KESETIMBANGAN KIMIA KELAS XI SMA/MA. https://doi.org/10.31227/osf.io/n7jkf

[33] Firdaus, A., \& Zainul, R. (2018, November 6). SESIUM KLORIDA (CsCl) :TRANSPORT ION DALAM LARUTAN. https://doi.org/10.31227/osf.io/rj6gy

[34] Chaidir, z., Zainul, R., Nurakhbari, D., \& Salim, M. (2018, July 29). Optimization of Spirulina Platensis Culture for Antioxidant Production. https://doi.org/10.17605/OSF.IO/FD6E4

[35] Lubis, A. P., \& Zainul, R. (2018, November 5). Interaksi Molekuler Amonium Hidroksida.https://doi.org/10.31227/osf.io/jht3b

[36] Setianto, S. (2017) "ANALISA KUANTITATIF CAMPURAN SENYAWA OKSIDA SEBAGAI DASAR IDENTIFIKASI KANDUNGAN BAHAN SUMBER DAYA ALAM Studi Kasus : Kandungan Mineral pada Pasir Besi di Pesisir Pantai Selatan, Jawa Barat", EKSAKTA: Berkala Ilmiah Bidang MIPA, 18(02), pp. 173-177. doi: 10.24036/eksakta/vol18-iss02/74.

[37] Putri, D., Fifendy, M. and putri, M. (2018) "DIVERSITAS BAKTERI ENDOFIT PADA DAUN MUDA DAN TUA TUMBUHAN ANDALEH (Morus macroura miq.)", EKSAKTA: Berkala Ilmiah Bidang MIPA, 19(1), pp. 125-130. doi: 10.24036/eksakta/vol19-iss1/122.

[38] Yanuar, F., Tillah, M. and Devianto, D. (2018) "Modeling of Human Development Index Using Ridge Regression Method", EKSAKTA: Berkala Ilmiah Bidang MIPA, 19(2), pp. 1-11. doi: 10.24036/eksakta/vol19-iss2/134.

[39] Suryelita, S., Etika, S. B. and Kurnia, N. S. (2017) "ISOLASI DAN KARAKTERISASI SENYAWA STEROID DARI DAUN CEMARA NATAL (Cupressus funebris Endl.)", EKSAKTA: Berkala Ilmiah Bidang MIPA, 18(01), pp. 86-94. doi: 10.24036/eksakta/vol18-iss01/23.

[40] Azhar, M., Ahda, Y., Ihsanawati, I., Puspasari, F., Mawarni, S., Risa, B. and Natalia, D. (2017) "SKRINING BAKTERI PENDEGRADASI INULIN DARI RIZOSFER UMBI DAHLIA MENGGUNAKAN INULIN UMBI DAHLIA", EKSAKTA: Berkala Ilmiah Bidang MIPA, 18(02), pp. 13-20. doi: 10.24036/eksakta/vol18-iss02/44. 
[41] Prabowo, H. (2018) "PENYELIDIKAN KELAYAKAN KIMIA DAN PENYEBARAN CADANGAN PASIR BESI DAERAH TIKU KABUPATEN AGAM UNTUK BAHAN BAKU SEMEN PADA PT. SEMEN PADANG", EKSAKTA: Berkala Ilmiah Bidang MIPA, 19(1), pp. 39-42. doi: 10.24036/eksakta/vol19-iss 1/121.

[42] Tutuarima, T. (2017) "SIFAT FISIK DAN KIMIA MARMALADE JERUK KALAMANSI (Citrus microcarpa) : KAJIAN KONSENTRASI PEKTIN DAN SUKROSA Physical and Chemical Properties of Marmalade Citrus of Calamondin (Citrus microcarpa) : Study of Pectin and Sucrose Concentrations", EKSAKTA: Berkala Ilmiah Bidang MIPA, 18(02), pp. 164-172. doi: 10.24036/eksakta/vol18-iss02/73.

[43] Susilaningrum, D. (2017) "PEMODELAN REGRESI LOGISTIK PADA FAKTOR YANG MEMPENGARUHI PHBS PADA RUMAH TANGGA PENDERITA TBC DI PESISIR SURABAYA", EKSAKTA: Berkala Ilmiah Bidang MIPA, 18(02), pp. 121-128. doi: 10.24036/eksakta/vol18iss02/65.

[44] Rahmi H.G, I. (2017) "TELAAH FAKTOR-FAKTOR YANG MEMPENGARUHI STATUS GIZI BALITA DI KOTA PADANG BERDASARKAN BERAT BADAN PER TINGGI BADAN MENGGUNAKAN METODE CART”, EKSAKTA: Berkala Ilmiah Bidang MIPA, 18(02), pp. 86-99. doi: 10.24036/eksakta/vol18-iss02/59.

[45] Hidayat, D. (2017) "IMPLEMENTASI PENGONTROL PID PADA MODEL FISIS ELEKTRONIK", EKSAKTA: Berkala Ilmiah Bidang MIPA, 18(02), pp. 178-185. doi: 10.24036/eksakta/vol18-iss02/75.

[46] Iskandar, I., Horiza, H. and Fauzi, N. (2017) "EFEKTIVITAS BUBUK BIJI PEPAYA (Carica Papaya Linnaeaus) SEBAGAI LARVASIDA ALAMI TERHADAP KEMATIAN LARVA AEDES AEGYPTY TAHUN 2015", EKSAKTA: Berkala Ilmiah Bidang MIPA, 18(01), pp. 1218. doi: 10.24036/eksakta/vol18-iss01/12.

[47] Badrulfalah, B. (2018) "SUB RUANG TUTUP TOPOLOGI HASIL KALI RUANG METRIK KERUCUT”, EKSAKTA: Berkala Ilmiah Bidang MIPA, 19(1), pp. 63-67. doi: 10.24036/eksakta/vol19-iss1/128.

[48] Hidayat, D. (2018) "ANALISIS RESPON PENGONTROL ON-OFF PADA KENDALI UMPAN BALIK SISTEM FISIS ELEKTRONIK", EKSAKTA: Berkala Ilmiah Bidang MIPA, 19(1), pp. 118-124. doi: 10.24036/eksakta/vol19-iss1/119.

[49] Santoso, B. (2018) "IDENTIFIKASI AKUIFER MENGGUNAKAN METODE GEOLISTRIK RESISTIVITAS DI DAERAH BEBANDEM, KARANG ASEM, BALI", EKSAKTA: Berkala Ilmiah Bidang MIPA, 19(1), pp. 24-34. doi: 10.24036/eksakta/vol19-iss1/101.

[50] Advinda, L. (2018) "PERTUMBUHAN STEK HORIZONTAL BATANG JARAK PAGAR (Jatropha curcas L.) YANG DIINTRODUKSI 
DENGAN PSEUDOMONAD FLUORESEN", EKSAKTA: Berkala Ilmiah Bidang MIPA, 19(1), pp. 68-75. doi: 10.24036/eksakta/vol19-iss1/129.

[51] Iryani, I., Iswendi, I. and Katrina, I. T. (2017) "UJI AKTIVITAS ANTI DIABETES MELLITUS SENYAWA METABOLIT SEKUNDER FRAKSI AIR DARI BERAS KETAN HITAM ( Oryza satival. Var glutinosa) PADA MENCIT PUTIH”, EKSAKTA: Berkala Ilmiah Bidang MIPA, 18(01), pp. 54-60. doi: 10.24036/eksakta/vol18-iss01/17.

[52] Sudrajat, R. (2017) "TINJAUAN TENTANG KETERKAITAN PARAMETER DENGAN MODEL REGRESI MULTIVARIAT PADA KOLAM IKAN TERTUTUP”, EKSAKTA: Berkala Ilmiah Bidang MIPA, 18(02), pp. 158-163. doi: 10.24036/eksakta/vol18-iss02/72.

[53] Putri, D., Anika, M. and Wahyuni, W. (2019) "Bioinformatics Study Genes Encoding Enzymes Involved in the Biosynthesis of Carotenoids Line Cassava (Manihot esculenta)", EKSAKTA: Berkala Ilmiah Bidang MIPA, 20(1), pp. 10-16. doi: 10.24036/eksakta/vol20-iss1/161.

[54] Joebaedi, K. (2018) "MODEL STAR(1;1) PADA DATA PRODUKTIVITAS TEH”, EKSAKTA: Berkala Ilmiah Bidang MIPA, 19(1), pp. 35-38. doi: 10.24036/eksakta/vol19-iss1/118.

[55] Amananti, W. (2017) “ANALISIS MIKROSTRUKTUR LAPISAN TIPIS TiO2:ZnO YANG DIDEPOSISIKAN DIATAS SUBTRAT KACA DENGAN METODE SPRAY COATING UNTUK DEGRADASI LIMBAH ZAT WARNA", EKSAKTA: Berkala Ilmiah Bidang MIPA, 18(02), pp. 210-215. doi: 10.24036/eksakta/vol18-iss02/81.

[56] Enjelina, W., Mansyurdin, M. and Meideliza, T. (2018) "Analysis of Nepenthes Hybrids in Bukik Taratak West Sumatra by RAPD Technique", EKSAKTA: Berkala Ilmiah Bidang MIPA, 19(2), pp. 12-20. doi: 10.24036/eksakta/vol19-iss2/137.

[57] Syafei, N., Hidayat, D., Emilliano, E. and Men, L. (2018) “Analysis Cracking Corrosion on Carbon Steel Pipes API 5L-X65 In Solution 7700 $\mathrm{ml}$ Aquades, $250 \mathrm{ml}$ Acetic Acid and $50 \mathrm{ml}$ Ammonia with Gas CO2 and $\mathrm{H} 2 \mathrm{~S}$ in Saturation Condition", EKSAKTA: Berkala Ilmiah Bidang MIPA, 19(2), pp. 21-31. doi: 10.24036/eksakta/vol19-iss2/138.

[58] Santoso, B., Setianto, S., Hasanah, M., Wijatmoko, B., Supriyana, E. and Mohammad, H. (2018) "Mitigation of Land Movement using Self Potential Method in Ling-Anjung Region Sumedang Regency", EKSAKTA: Berkala Ilmiah Bidang MIPA, 19(2), pp. 32-39. doi: 10.24036/eksakta/vol19-iss2/141.

[59] Dinata, M. and Soehardi, F. (2018) "Factor Analysis of Physics Chemistry Waters that Affects Damage Safety Cliff on the Outskirts of River Siak”, EKSAKTA: Berkala Ilmiah Bidang MIPA, 19(2), pp. 46-49. doi: 10.24036/eksakta/vol19-iss2/143. 
[60] Harahap, F. and Lubis, L. (2018) "Analysis of Heavy Metals Distribution in the River Town of Hamasaki's Rod Padangsidimpuan", EKSAKTA: Berkala Ilmiah Bidang MIPA, 19(2), pp. 50-56. doi: 10.24036/eksakta/vol19-iss2/149.

[61] Badrulfalah, B., Irianingsih, I. and Joebaedi, K. (2018) "Some Operations on Mixed Monotone Operator in Banach Spaces", EKSAKTA: Berkala Ilmiah Bidang MIPA, 19(2), pp. 57-61. doi: 10.24036/eksakta/vol19iss $2 / 150$.

[62] Joebaedi, K., Parmikanti, K. and Badrulfalah, B. (2018) "First Order Space Time Autoregressive Stationary Model on Petroleum Data", EKSAKTA: Berkala Ilmiah Bidang MIPA, 19(2), pp. 62-69. doi: 10.24036/eksakta/vol19-iss2/152.

[63] Sofyanita, S. and Octaria, Z. (2018) "Fenthion Compound Degradation in the Pesticide Bayleton 500 ec in Sonolysis, Ozonolysis and Sonozolysis with Addition of TiO2-anatase", EKSAKTA: Berkala Ilmiah Bidang MIPA, 19(2), pp. 70-79. doi: 10.24036/eksakta/vol19-iss2/153.

[64] Vauzia, V. and Gusmira, E. (2018) “The Response of Jabon Seeds Germination (Anthocephalus cadamba (Roxb.)Miq.) against the Duration of Combustion and Illumination", EKSAKTA: Berkala Ilmiah Bidang MIPA, 19(2), pp. 80-87. doi: 10.24036/eksakta/vol19-iss2/154.

[65] Fati, N., Siregar, R. and Sujatmiko, S. (2019) "Addition Of Coleus Amboinicus, L Leaf's Extract In Ration To Percentage Of Carcass, Abdominal Fat, Liver And Heart Broiler", EKSAKTA: Berkala Ilmiah Bidang MIPA, 20(1), pp. 1-9. doi: 10.24036/eksakta/vol20-iss1/157.

[66] Suratno, T., Rarasati, N. and Z G. (2019) "Optimization of Genetic Algorithm for Implementation Designing and Modeling in Academic Scheduling", EKSAKTA: Berkala Ilmiah Bidang MIPA, 20(1), pp. 17-24. doi: 10.24036/eksakta/vol20-iss1/166.

[67] Ramalisa, Y., Febriyanti, A. and Multahadah, C. (2019) "Analysis of Non Hierarchical Bomb for Collection of Community Health Degrees in Jambi and Muaro Jambi City”, EKSAKTA: Berkala Ilmiah Bidang MIPA, 20(1), pp. 25-34. doi: 10.24036/eksakta/vol20-iss1/167.

[68] Pasaribu, F., Mardia, A. and Sormin, C. (2019) "Ordinal Logistic Regression with an Application to Health Service Quality in Raden Mattaher Jambi Hospital", EKSAKTA: Berkala Ilmiah Bidang MIPA, 20(1), pp. 35-40. doi: 10.24036/eksakta/vol20-iss1/168.

[69] Badrulfalah, B., Susanti, D., Joebaedi, K. and Kosasih, R. (2019) "Some Properties of Green's Matrix of Nonlinear Boundary Value Problem of First Order Differential”, EKSAKTA: Berkala Ilmiah Bidang MIPA, 20(1), pp. 41-47. doi: 10.24036/eksakta/vol20-iss1/173.

[70] Joebaedi, K., Susanti, D., Warwah, N., Parmikanti, K. and Badrulfalah, B. (2019) "Factors Affecting the Amount of Investment Loans in 
Commercial Banks with the Application of Linear Regression Analysis Methods", EKSAKTA: Berkala Ilmiah Bidang MIPA, 20(1), pp. 48-54. doi: 10.24036/eksakta/vol20-iss1/172.

[71] Suhaemi, Z., Zulkarnaini, Z., Afrijon, A. and Jefri, P. (2019) "The Study of African Leave (Vernonia amygdalina) in for Improving the Quality of Local Duck Meats of West Sumatera", EKSAKTA: Berkala Ilmiah Bidang MIPA, 20(1), pp. 55-59. doi: 10.24036/eksakta/vol20-iss1/174.

[72] Afnuhazi, R. (2019) "Bivariate Analysis on Autism Therapy using Social Skills Training in SLB YPPA Padang”, EKSAKTA: Berkala Ilmiah Bidang MIPA, 20(1), pp. 60-76. doi: 10.24036/eksakta/vol20-iss1/175.

[73] Dinata, M., Fitridawati, F. and Putri, L. (2019) "The Study Trees Potential for Forest in Universitas Lancang Kuning Pekanbaru", EKSAKTA: Berkala Ilmiah Bidang MIPA, 20(1), pp. 77-85. doi: 10.24036/eksakta/vol20-iss1/176.

[74] Syafei, N. (2019) "Events of corrosion phenomena on carbon steel pipes in environment of sea water and ammonia solutions due to the presence of sweet gas”, EKSAKTA: Berkala Ilmiah Bidang MIPA, 20(1), pp. 86-99. doi: 10.24036/eksakta/vol20-iss1/178.

[75] Zainul, R. and Wardani, S. (2019) "The Hydrogen Generator Performance of Sandwich Designed 4/4 Al-Cu Plates", EKSAKTA: Berkala Ilmiah Bidang MIPA, 20(1), pp. 100-104. doi: 10.24036/eksakta/vol20-iss1/177.

[76] M., Sanjaya, H., \& Zainul, R. (2018, August 11). Characterization of napa soil and adsorption of $\mathrm{Pb}$ (II) from aqueous solutions using on column method. https://doi.org/10.31227/osf.io/t8fh9

[77] P, O. M., A, L. G., S, A. Y. M., \& Zainul, R. (2018, October 12). A Review Grinding : Teknik dan Prinsip Dasar pada Pengolahan Material. https://doi.org/10.31227/osf.io/trv4q

[78] Y., \& Zainul, R. (2018, November 18). SILVER SULFATE (Ag2SO4): MOLECULAR ANALYSIS AND ION TRANSPORT. https://doi.org/10.31227/osf.io/n8g9k

[79] H., Azhar, M., \& Zainul, R. (2018, September 19). THE EFFECTIVENESS OF STRUCTURED INQUIRY BASED MODULE TO IMPROVE MENTAL MODEL OF CONCEPT MOLE. https://doi.org/10.31227/osf.io/ckjtb

[80] H., Sanjaya, H., \& Zainul, R. (2018, August 11). Synthesis and Electrical Properties of ZnO-ITO and Al-ITO thin Film by Spin Coating Technique Through Sol Gel Process. https://doi.org/10.31227/osf.io/unrt4

[81] Dwynda, I., \& Zainul, R. (2018, November 19). Boric Acid (H3 (BO3): Recognize The Molecular Interactions in Solutions. https://doi.org/10.31227/osf.io/6wead 
[82] Artika, P. I., \& Zainul, R. (2018, November 19). Potassium Bromide (KBr): Transformasi ionik dan sifat temodinamika dalam Larutan. https://doi.org/10.31227/osf.io/a5hyz

[83] Sari, M., \& Zainul, R. (2018, November 19). Kalium Dikromat (K2Cr2O7) Spektroskopi dan Transpor K2Cr2O7. https://doi.org/10.31227/osf.io/w92je

[84] Yanti, C. F., \& Zainul, R. (2018, December 2). A Review Ba (OH)2 : Transpor Ionik pada Barium Hidroksida di dalam Air dengan Konsep Termodinamika. https://doi.org/10.31227/osf.io/fsbq3

[85] Yulis, R., Zainul, R., \& M. (2018, December 10). DESAIN DAN KARAKTERISASI SEL SURYA SISTEM ELEKTRODA TEMBAGA (I) OKSIDA (Cu2O/Al) MODEL PIPA PADA LARUTAN NATRIUM SULFAT (Na2SO4). https://doi.org/10.31227/osf.io/m43js

[86] Putri, G. E., Arief, S., Jamarun, N., Gusti, F. R., \& Zainul, R. (2018, December 10). Microstuctural Analysis and Optical Properties of Nanocrystalline Cerium Oxides Synthesized by Precipitation Method. https://doi.org/10.31227/osf.io/qcz4y

[87] Rahmadhanty, S., \& Zainul, R. (2018, December 24). DESIGN OF HUMAT ACID SOLID SOLUTION REACTOR THROUGH PHOTOTRANSFORMATION OF COPPER OXIDE (CuO) SEMICONDUCTOR PLATE. https://doi.org/10.31227/osf.io/yhd9x

[88] Hakimi, A., \& Zainul, R. (2019, January 31). Asam Arsenat (H3AsO4) : Analisis Molekular dan Karakteristik Senyawa. https://doi.org/10.31227/osf.io/e486z

[89] Hidayati, R., \& Zainul, R. (2019, January 31). Studi Termodinamika Transpor Ionik Natrium Klorida Dalam Air dan Campuran Tertentu. https://doi.org/10.31227/osf.io/e87sq

[90] Warlinda, Y. A., \& Zainul, R. (2019, January 29). Asam Posfat (H3PO4): Ionic Transformation of Phosphoric Acid in Aqueous Solution. https://doi.org/10.31227/osf.io/s3y8v

[91] Kristy, D. P., \& Zainul, R. (2019, February 3). Analisis Molekular dan Transpor Ion Natrium Silikat. https://doi.org/10.31227/osf.io/8ac4m

[92] Rhaska, G., \& Zainul, R. (2019, January 31). Analisis Molekular dan Transpor Ion Amonium Clorida. https://doi.org/10.31227/osf.io/gwhtq

[93] Sari, E. S. J., \& Zainul, R. (2019, January 31). Nitrogen Triflorida (NF3) : Termodinamika dan Transpor Elektron NF3. https://doi.org/10.31227/osf.io/3nzrh

[94] Aura, S. M., \& Zainul, R. (2019, February 3). KARAKTERISASI DAN INTERAKSI MOLEKULAR ASAM SULFAT. https://doi.org/10.31227/osf.io/tnjxb 
[95] Yuliani, F., \& Zainul, R. (2018, November 13). Analisis Termodinamika Molekul Magnesium Sulphate (MgSO4). https://doi.org/10.31227/osf.io/uxz4y

[96] Jumalia, R., \& Zainul, R. (2019, February 3). Natrium Karbonat : Termodinamika dan Transport Ion. https://doi.org/10.31227/osf.io/y2vq9

[97] Delvi, I. P., \& Zainul, R. (2019, February 3). Mercury (II) Nitrate (Hg (NO3)2): Interaksi Molekul dan Adsorpsi $\mathrm{Hg}$ dengan Karbon Aktif. https://doi.org/10.31227/osf.io/eqyax

[98] Shafitri, M., \& Zainul, R. (2019, February 3). Vanadium Pentaoksida (V2O5) : Termodinamika Molecular dan Interaksi Ion dalam Larutan. https://doi.org/10.31227/osf.io/jgmvd

[99] Nurfadilah, K. K., \& Zainul, R. (2019, February 3). Kalium Nitrat (KNO3): Karakteristik Senyawa dan Transpor Ion. https://doi.org/10.31227/osf.io/dr8ef

[100] Husna, A. D., \& Zainul, R. (2019, February 4). Analisis Molekular dan $\begin{array}{lll}\text { Karakteristik Hidrogen } & \text { Sianida }\end{array}$ https://doi.org/10.31227/osf.io/7xej9

[101] Zainul, R., Alif, A., Aziz, H., Arief, S., \& s. (2018, August 16). Photoelectrosplitting Water Mechanism at Carbon Electrode Surface using Indoor lights. https://doi.org/10.31227/osf.io/vcxq8

[102] Alfionita, T., \& Zainul, R. (2019, January 29). Calcium Chloride (CaCl2) : Characteristics and Molecular Interaction in Solution. https://doi.org/10.31227/osf.io/m37xj

[103] Zainul, R., \& Dewata, I. (2018, August 16). Determination of pH-BODCOD and degradation in batang arau watersheds at Padang city. https://doi.org/10.31227/osf.io/efdzj

[104] Awalliyah, A., Ikhwan, H., Nugiasari, V., \& Zainul, R. (2018, October 15). A REVIEW PRINSIP DASAR MILLING DALAM SINTESIS MATERIAL. https://doi.org/10.31227/osf.io/9xsqe

[105] Febriani, S. S., Yolanda, T., Arianti, V. A., \& Zainul, R. (2018, October 12). A Review Solid Stated : Principles and Methode. https://doi.org/10.31227/osf.io/7us4x

[106] Zainul, R. (2018, August 16). Effect of Temperature and Particle Motion against the ability of $\mathrm{ZnO}$ Semiconductor Photocatalyst in Humic Acid. https://doi.org/10.31227/osf.io/wnygb

[107] Zainul, R. (2018, August 16). Determination of the half-life and the quantum yield of $\mathrm{ZnO}$ semiconductor photocatalyst in humic acid. https://doi.org/10.31227/osf.io/e8a9x

[108] Candani, D., Ulfah, M., Noviana, W., \& Zainul, R. (2018, October 19). A Review Pemanfaatan Teknologi Sonikasi. https://doi.org/10.31227/osf.io/uxknv 
[109] Tamarani, A., Zainul, R., \& Dewata, I. (2018, December 9). Preparation and Characterization of XRD Nano Cu-TiO2 using Sol-Gel Method. https://doi.org/10.31227/osf.io/2qu4e

[110] Fatimah, P., Jumalia, R., Novianti, E. R., \& Zainul, R. (2018, October 15). A REVIEW Teknik Blended : Prinsip dan Dasar-Dasar. https://doi.org/10.31227/osf.io/tm2w4

[111] M., Yani, S. R., \& Zainul, R. (2018, August 31). Aktivasi Tanah Napa dan Pengaruhnya Terhadap Adsorpsi Ion Timbal (II)/ $\mathrm{Pb} 2+$. https://doi.org/10.31227/osf.io/ps523

[112] Zainul, R., Oktavia, B., Dewata, I., \& efendi, j. (2018, August 16). Studi Dinamika Molekular dan Kinetika Reaksi pada Pembelahan Molekul Air untuk Produksi Gas Hidrogen. https://doi.org/10.31227/osf.io/876s3

[113] Zainul, R., \& W. (2019, February 3). Magnesium Klorida ( $\mathrm{MgCl} 2)$ : Karakteristik dan Dinamika Molekuler Pada $\mathrm{MgCl} 2$. https://doi.org/10.31227/osf.io/g3w8p

[114] Anhar, A., Sumarmin, R., \& Zainul, R. (2018, August 11). Measurement of Glycemic Index of West Sumatera Local Rice Genotypes for Healthy Food Selection. https://doi.org/10.31227/osf.io/tgy8h

[115] W., \& Zainul, R. (2019, February 3). Magnesium Klorida ( $\mathrm{MgCl} 2)$ : Karakteristik dan Dinamika Molekuler Pada $\mathrm{MgCl} 2$. https://doi.org/10.31227/osf.io/9cjdp

[116] marpaung, f. o. (2018, November 6). PRINSIP AGROEKOSISTEM DALAM KONSERVASI SUMBER DAYA ALAM. https://doi.org/10.31227/osf.io/c97vd

[117] Sagala, D. (2018, February 10). Deskripsi, Metabolit Sekunder dan Kegunaan Anyang-Anyang (Elaeocarpus grandiflorus J.E. Smith). https://doi.org/10.31227/osf.io/3unv8

[118] Asmarani, N. O. (2018, March 7). Nilai Ekofeminisme dalam Tumpek Wariga sebagai Kearifan Lokal Bali dalam Melestarikan Alam. https://doi.org/10.31227/osf.io/7p48m

[119] Merdekawati, W. (2018, January 1). Rumput Laut, Makanan Sehat Abad 21. https://doi.org/10.31227/osf.io/3427n

[120] Hanum, F., Nugrahani, E. H., \& Susanti, S. (2018, January 16). Pemanfaatan Sumber Daya Alam Terbarukan dalam Model Sewa Ekonomi. https://doi.org/10.31227/osf.io/fxs2h

[121] Febriana, A. (2017, December 6). Uji Aktivitas Antibakteri Ekstrak Etanol Umbi Batang Tumbuhan Sarang Semut (Myrmecodia Pendens Merr. \& L. M. Perry) Terhadap Pseudomonas Aeruginosa Dan Staphylococcus Aureus. https://doi.org/10.31227/osf.io/9ak3h

[122] Thressia, M., \& Shinta, D. Y. (2019, January 9). PEMANFAATAN LIMBAH KULIT MELINJO YANG MEMPUNYAI AKTIVITAS ANTI 
BAKTERI TERHADAP BAKTERI PATHOGEN GRAM NEGATIF (Escherichia coli). https://doi.org/10.31227/osf.io/vjcp5

[123] Ngibad, K. (2018, May 9). KANDUNGAN SENYAWA KIMIA DAN BIOAKTIVITAS DARI SELAGINELLA DOEDERLEINII HIERON. https://doi.org/10.31227/osf.io/u4ght

[124] 2017, S. N. M. I., \& Lestari, W. (2017, November 6). ISOLASI DAN UJI ANTIFUNGAL BAKTERI ENDOFIT DARI AKAR TANAMAN KARET (Hevea brasilliensis). https://doi.org/10.31227/osf.io/xb9a5

[125] Hakiki, R. (2018, May 16). Tumpang Sari Tanaman Jagung Manis. https://doi.org/10.31227/osf.io/3h8g7

[126] B. (2018, June 2). PEMANFAATAN BUAH BERENUK (Crescentia cujete Linn) SEBAGAI BAHAN BAKU PEMBUATAN BIOETANOL. https://doi.org/10.31227/osf.io/2kxcv

[127] H. (2017, November 12). PEMANFAATAN JERAMI PADI DENGAN BERBAGAI TEKNOLOGI PENGOLAHAN PAKAN TERHADAP PERSENTASE NON KARKAS DAN PERSENTASE DAGING TANPA TULANG PADA DOMBA JANTAN LOKAL. https://doi.org/10.31227/osf.io/yqt23

[128] Solihin, A. P. (2018, January 9). Uji Toksisitas Ekstrak Akar Tuba Terhadap Keong Mas. https://doi.org/10.31227/osf.io/2ujhq

[129] Mektildis, R. (2018, October 18). Formulasi Krim Ekstrak Etanol Kulit Batang Faloak (Sterculia Quadrifida R.Br). https://doi.org/10.31227/osf.io/q57ye

[130] kusumaningrum, w., \& Sodik, M. A. (2018, October 21). Kegunaan Daun Sirsak Sebagai Pembunuh Sel Kanker. https://doi.org/10.31227/osf.io/uac2k

[131] Indrianti, M. A. (2019, March 27). ANALISA POTENSI ECENG GONDOK (Eichhornia crassipes ) DANAU LIMBOTO SEBAGAI PAKAN TERNAK. Retrieved from osf.io/preprints/inarxiv/sxj45

[132] S. (2018, April 23). KORELASI PERTUMBUHAN ORGAN VEGETATIF DENGAN PRODUKSI KEDELAI (Glycine max, (L) Merill. https://doi.org/10.31227/osf.io/9enb3

[133] Fauzi, I. G., Ananda, R., Sari, I. N., \& Gultom, M. D. P. (2019, April 29). Pembuatan Sabun Mandi Padat dengan Menggunakan VCO Campuran Ekstrak Wortel. https://doi.org/10.31227/osf.io/bjz8f

[134] Rifai, Y. (2017, December 6). Biosintesis Nanopartikel Perak Menggunakan Ekstrak Metanol Daun Kemangi (Ocimum Citriodorum). https://doi.org/10.31227/osf.io/w2a5e

[135] Buaton, R. (2018, September 25). PERANCANGAN SISTEM PAKAR MENDIAGNOSA PENYAKIT GINJAL DENGAN PENGOBATAN HERBAL. https://doi.org/10.31227/osf.io/agx3 
[136] Manurung, N. (2017, November 25). Hubungan pelaksanaan oral hygiene dengan kejadian infeksi rongga mulut. https://doi.org/10.31227/osf.io/bfcg9

[137] Garnadi, A. D. (2017, December 16). Simulasi Perambatan Cahaya pada Biomaterial dengan Kandungan Zat Pewarna Menggunakan Metode Elemen Hingga. https://doi.org/10.31227/osf.io/kh326

[138] Mutmainnah, P. A. (2018, May 7). IDENTIFIKASI SENYAWA TURUNAN HASIL FRAKSINASI KAYU AKAR ARTOCARPUS ODORATISSIMUS. https://doi.org/10.31227/osf.io/rtsx8

[139] jarti, n., \& Jarti, N. (2018, September 13). SISTEM PAKAR DIAGNOSA PENYAKIT ALERGI PADA ANAK BERBASIS WEB DENGAN METODE FORWARD CHAINING DI KOTA BATAM. https://doi.org/10.31227/osf.io/x7ksz

[140] Wadakusuma, D., \& Afandi, A. F. (2018, June 8). TANAMAN HIDROPONIK ALAMI TANPA BAHAN KIMIA. https://doi.org/10.31227/osf.io/d4vu3

[141] M. (2019, January 18). Manfaat hutan mangrove untuk kehidupan masyarakat. https://doi.org/10.31227/osf.io/gzecb

[142] Djano, N. A. R. (2018, July 5). PENGARUH KUALITAS PELAYANAN KESEHATAN TERHADAP MINAT PASIEN DALAM MEMANFAATKAN KEMBALI JASA PELAYANAN RAWAT JALAN DI PUSKESMAS WARA UTARA KECAMATAN BARA KOTA PALOPO TAHUN 2016. https://doi.org/10.31227/osf.io/wqxrh

[143] 2017, S. N. M. I., \& Efendi, E. (2017, November 3). PENDAYAGUNAAN AIR LIMBAH RUMAH TANGGA UNTUK PRODUKSI SAWI ORGANIK. https://doi.org/10.31227/osf.io/54wdf

[144] Suryani, S. I., \& Sodik, M. A. (2018, October 21). Perilaku Cuci Tangan Pakai Sabun Mencegah Diare. https://doi.org/10.31227/osf.io/54w87

[145] Rudi, A. (2017, December 2). DETERMINAN YANG BERHUBUNGAN DENGAN KEJADIAN PENYAKIT TYPUS PADA MASYARAKAT DI DESA TANJUNG HULU KECAMATAN SEPAUK. https://doi.org/10.31227/osf.io/643f2

[146] Ramli, R., Jonuarti, R. and Hartono, A. (2017) “ANALISIS STRUKTUR NANO DARI LAPISAN TIPIS COBALT FERRITE YANG DIPREPARASI DENGAN METODE SPUTTERING”, EKSAKTA: Berkala Ilmiah Bidang MIPA, 18(01), pp. 46-53. doi: 10.24036/eksakta/vol18-iss01/16.

[147] Handayani, D. (2017) "KARAKTERISTIK CENDAWAN DARK SEPTATE ENDOPHYTE (DSE) PADA AKAR TANAMAN JAGUNG DAN PADI", EKSAKTA: Berkala Ilmiah Bidang MIPA, 18(01), pp. 6168. doi: 10.24036/eksakta/vol18-iss01/20. 
[148] Permana, D. (2017) "MODEL STOKASTIK RANTAI MARKOV EMPAT STATUS PADA PENENTUAN NILAI HIDUP PELANGGAN", EKSAKTA: Berkala Ilmiah Bidang MIPA, 18(01), pp. 78-85. doi: 10.24036/eksakta/vol18-iss01/22.

[149] Saluza, I. (2017) "MODEL ESTIMASI GARCH DALAM MENGUKUR KINERJA NILAI TUKAR RUPIAH", EKSAKTA: Berkala Ilmiah Bidang MIPA, 18(02), pp. 52-61. doi: 10.24036/eksakta/vol18-iss02/53.

[150] Prihatini R. PEMANFAATAN AIR KELAPA UNTUK MENINGKATKAN PERTUMBUHAN AKAR STEK TUNAS AKSILAR Andrographis paniculata Nees. EKSAKTA [Internet]. 30Nov.2017 [cited 12May2019];18(02):62-8. Available from: http://eksakta.ppj.unp.ac.id/index.php/eksakta/article/view/54 